\title{
Metode Menghafal Alquran Tawazun Dan Peningkatan Self-Esteem Santri di Pesantren Daarul Huffadz Indonesia
}

\author{
Nida Syauqia Albi \\ Prodi Pendidikan Agama Islam, Fakultas Ilmu Sosial, Universitas Negeri Jakarta
}

NidaSyauqiaAlbi_4715164148@mhs.unj.ac.id

Andy Hadiyanto

Prodi Pendidikan Agama Islam, Fakultas Ilmu Sosial, Universitas Negeri Jakarta

andy-hadiyanto@unj.ac.id

\author{
Ahmad Hakam \\ Prodi Pendidikan Agama Islam, Fakultas Ilmu Sosial, Universitas Negeri Jakarta \\ ahmad-hakam@unj.ac.id \\ Firdaus Wajdi \\ Prodi Pendidikan Agama Islam, Fakultas Ilmu Sosial, Universitas Negeri Jakarta \\ firdaus.wajdi@unj.ac.id
}

\begin{abstract}
This article explains the learning of memorizing the Koran by the Tawazun Method in the Daarul Huffadz Indonesian Boarding School, Sentul Branch. This research was conducted with a qualitative approach. The data collection method consists of interviews and document studies. The results showed that learning to memorize the Koran with the Tawazun Method consists of the process of reading, understanding, imagining, memorizing and depositing. These activities train the intelligence of the right brain and left brain in a balanced and optimal way. This method proved useful in facilitating students in memorizing the Koran; gain an understanding of the Qur'an; strengthen and maintain memorization; foster motivation to memorize and create intensive relations between students and the Koran. The implementation of the Tahfidz method also contributes positively to the improvement of personal selfesteem which is characterized by an increase in feelings of happiness, the ability to face challenges, overcome problems, and motivate him; and good self-acceptance by the environment and good relations with other individuals or groups.
\end{abstract}

Keywords: Tawazun Method, Daarul Huffadz of Indonesia, Self-esteem.

\begin{abstract}
Abstrak
Artikel ini menjelaskan pembelajaran menghafal Alquran dengan Metode Tawazun di Pesantren Daarul Huffadz Indonesia Cabang Sentul. Penelitian ini dilaksanakan dengan pendekatan kualitatif. Metode pengumpulan datanya terdiri atas wawancara dan studi dokumen. Hasil penelitian menunjukkan bahwa pembelajaran menghafal Alquran dengan Metode Tawazun terdiri atas proses membaca, memahami, membayangkan, menghafalkan dan menyetorkan. Aktivitas tersebut melatih kecerdasan otak kanan dan otak kiri secara seimbang dan optimal. Metode ini terbukti bermanfaat dalam memudahkan santri dalam menghafal Alquran; memperoleh pemahaman tentang Alquran; menguatkan dan menjaga hafalan;
\end{abstract}


menumbuhkan motivasi untuk menghafal serta menciptakan hubungan yang intensif antara santri dengan Alquran. Implementasi metode tahfidz ini juga memberikan kontribusi positif terhadap peningkatan personal self-esteem yang ditandai dengan peningkatan perasaan bahagia, kemampuan dalam menghadapi tantangan, mengatasi masalah, dan memotivasi dirinya; serta penerimaan diri yang baik oleh lingkungannya dan hubungan yang baik dengan individu atau kelompok lain.

Kata Kunci: Metode Tahfidz Tawazun, Daarul Huffadz Indonesia, Self-esteem

\section{A. Pendahuluan}

Hilangnya kebermaknaan hidup (Self-esteem) ada kaitannya dengan tingkat religiusitas individu yang rendah ${ }^{1}$. Berdasarkan teori Glock dan Stark dalam Annisa Fitriani, relevansi antara self-esteem dan religiositas yaitu terletak pada dimensi feeling atau penghayatan. Salah satu aspek penghayatan yang dimaksud adalah berinteraksi dengan Alquran seperti membacanya, menghafalnya, dan menghayati ayat-ayatnya. Di samping itu, berinteraksi dengan Alquran juga termasuk ke dalam dimensi peribadatan dan pengetahuan. Dimensi pengetahuan terkait sejauh mana seseorang menerima doktrin agama yang diperolehnya dari kitab suci ${ }^{2}$. Saat ini masih banyak Muslim yang kurang berinteraksi dengan Alquran. Salah satu faktor penghambat kurangnya seorang Muslim berinteraksi dengan Alquran yaitu karena putus asa ketika mengalami kesulitan dalam belajar Alquran, baik belajar membaca, menghafal, atau memahami ayat Alquran.

Dalam Alquran terdapat doktrin tentang kebahagiaan yang kekal (surga) bagi orang yang bertakwa (QS. Maryam [19]:63). Orang yang bertakwa adalah mereka yang melaksanakan segala perintah-Nya dan menjauhi larangan-Nya. Doktrin tersebut dapat memberikan kebahagiaan, motivasi, dan kebermaknaan hidup bagi seseorang yang berinteraksi dengan Alquran. Schutz dalam Gita Windi Pangesti menjelaskan bahwa kebermaknaan hidup akan memberikan nilai-nilai dan harga diri yang positif pada individu. Sehingga seseorang akan menunjukkan sikap dan perilaku positif ${ }^{3}$.

Sebuah penelitian menunjukkan bahwa orang yang menghafal Alquran akan merasa tenang, tenteram, dan bahagia dikarenakan sering mengingat Allah melalui kajian-kajian

\footnotetext{
${ }^{1}$ Nuzulul Hikmah Balighoh, "Hubungan Antara Religiusitas Dan Kebermaknaan Hidup Dengan Kebahagiaan Penghafal Al-Qur'an Dewasa Awal” (Yogyakarta, 2018).

2 Annisa Fitriani, "Peran Religiusitas Dalam Meningkatkan Psychological Well Being” xi, no. 1 (2016).

${ }^{3}$ Gita Windi Pangesti, "Efektivitas Tadabbur Surah Al-Insyirah Terhadap Kebermaknaan Hidup Narapidana Muslim Di Lembaga Pemasyarakatan Perempuan (LPP) Klas II B Wirogunan Yogyakarta" (Universitas Islam Negeri Sunan Kalijaga, 2019).
} 
yang mereka lakukan ${ }^{4}$. Namun, tidak semua penghafal Alquran dapat merasakan hal tersebut. Masih banyak para penghafal Alquran yang diliputi perasaan malas, putus asa, dan kehilangan kenikmatan ketika berinteraksi dengan Alquran ${ }^{5}$. Selain itu, terkadang penghafal Alquran malas untuk mengulang hafalan Alquran (muroja'ah). Sikap tersebut mengindikasikan rendahnya self-esteem pada sebagian penghafal Alquran. Selain itu, mayoritas Muslim yang bermimpi untuk menghafal Alquran merasa ragu dan putus asa untuk menghafal Alquran karena masih menganggap jika menghafal Alquran itu sulit.

Berdasarkan permasalahan di atas ada satu metode menghafal Alquran yang dianggap mampu memudahkan seseorang dalam menghafal Alquran dan dapat meningkatkan self-esteem yaitu Metode Tawazun. Metode ini memadukan antara otak kanan dan otak kiri; yang memungkinkan santri dapat hafal, paham dan mutqin. Selain itu, metode ini telah berhasil membantu santri menghafal Alquran 30 juz dengan paham dan mutqin. Metode ini ditemukan dan dikembangkan oleh Ustadz Fuardi. Metode ini sudah diterapkan di 13 cabang Pesantren Tahfidz Daarul Huffadz Indonesia di berbagai daerah di Indonesia.

Dengan demikian, perlu dilakukan sebuah penelitian untuk mengetahui apakah Metode Tawazun dalam menghafal Alquran dapat memberikan kontribusi terhadap peningkatan self-esteem santri atau tidak. Oleh karena itu, penulis tertarik untuk melaksanakan penelitian dengan judul "Kontribusi Metode Menghafal Alquran Tawazun terhadap Peningkatan Self-esteem Santri di Pesantren Daarul Huffadz Indonesia Cabang Sentul".

\section{B. Metode Penelitian/Metode Kajian}

Tempat pelaksanaan penelitian ini adalah Pondok Pesantren Tahfidz Daarul Huffadz Indonesia Cabang Sentul. Pesantren tersebut berlokasi di Jalan Bunga Gladiol No 9 Cluster Sierra Madre Sentul City, Babakan Madang, Citaringgul, Bogor Jawa Barat. Lokasi penelitian ini dipilih berdasarkan beberapa pertimbangan, yaitu: pertama, lokasi penelitian merupakan salah satu lembaga pendidikan Tahfidzul Quran yang berkomitmen untuk memfasilitasi kaum Muslim yang ingin menghafal Alquran; kedua, penerapan metode menghafal Al-Qur'an yang berbeda dengan lembaga lain; ketiga, metode yang digunakan di Pesantren Daarul Huffadz Indonesia telah berhasil mencetak para penghafal Alquran sekitar 177 santri; keempat, Pondok Pesantren Daarul Huffadz Indonesia Cabang Sentul merupakan

\footnotetext{
${ }^{4}$ Muthi' Fauziyyah and Usmi Karyani, "Kesejahteraan Siswa: Studi Komparatif Siswa Berdasar Keikutsertaan Kegiatan Tahfidz," Indigenous: Jurnal Ilmiah Psikologi 2, no. 2 (2017): 193-200.

${ }^{5}$ Wiwi Alawiyah Wahid, Cara Cepat Bisa Menghafal Al-Qur'an (Yogyakarta: DIVA Press, 2014).
} 
salah satu pesantren khusus putri yang rata-rata berusia 13- 20 tahun. Sehingga penulis tertarik untuk meneliti pelaksanaan metode menghafal Al-Qur'an tersebut.

Penelitian ini menggunakan pendekatan deskriptif kualitatif. Dalam penelitian ini, penulis menggunakan data primer dan data sekunder. Penulis memperoleh data primer dari subjek penelitian, yaitu dengan menggunakan cara pengambilan data langsung pada subjek penelitian. Sumber primer dalam penelitian ini yaitu pimpinan, guru, dan santri di Pesantren Tahfidz Daarul Huffadz Indonesia.

Prosedur dalam menentukan sampel merupakan cara peneliti dalam menentukan informan kunci atau kondisi sosial tertentu yang relevan dengan fokus penelitian ${ }^{6}$. Subjek penelitian yang terpilih dalam penelitian ini yaitu ustadzah sebanyak satu orang dan santri perempuan berusia sekitar 13-20 tahun sebanyak 8 orang. Penentuan kriteria tersebut berdasarkan pendapat Robins bahwa self-esteem individu akan menurun ketika remaja ${ }^{7}$. Penurunan self-esteem pada masa remaja hanya sedikit dan lebih banyak terjadi pada anak perempuan ${ }^{8}$. Sedangkan menurut Robins dalam Dilla menjelaskan bahwa penurunannya cukup drastis akibat perubahan secara biologis, kognitif, sosial, psikologis, maupun akademik ${ }^{9}$. Berdasarkan hasil penelitian Family Health Study menunjukkan bahwa penurunan self-esteem pada remaja perempuan terjadi sekitar usia 12-17 tahun.

\section{Hasil dan Pembahasan}

\section{Tentang Pesantren Tahfidz Daarul Huffadz Indonesia}

Penelitian ini Pesantren Tahfidz Daarul Huffadz Indonesia dilakukan di Pesantren Tahfidz Daarul Huffadz Indonesia yang berpusat di Bogor tepatnya di Jalan Angsana Blok D No. 3, Desa Sukadamai, Kecamatan Tanah Sareal, Kota Bogor 16165, Jawa Barat. Daarul Huffadz Indonesia atau DHI merupakan salah satu lembaga yang bergerak dalam bidang pendidikan Alquran. Didirikannya Pesantren Tahfidz DHI ini bertujuan untuk memfasilitasi kaum Muslim yang ingin menghafal Alquran dengan paham dan mutqin. Pesantren DHI didirikan sejak bulan Agustus tahun 2013 oleh Ustadz Marzul Fuardi, M.Pd.I bersama adik dan teman-temannya. Awalnya, pesantren ini hanya berupa rumah-rumah Quran yang

${ }^{6}$ Burhan Bungin, Metode Penelitian Sosial \& Ekonomi: Format-Format Kuantitatif Dan Kualitatif Untuk Studi Sosiologi, Kebijakan, Publik, Komunikasi, Manajemen, Dan Pemasaran Edisi Pertama. (Jakarta: Kencana Prenada Media Group, 2013).

7 John W Santrock, Perkembangan Anak, 11th ed. (Jakarta: PT Erlangga, 2007).

${ }^{8}$ Ibid.

${ }^{9}$ Dilla Tria Febrina, Puji Lestari Suharso, and Airin Yustikarini Saleh, "Self-Esteem Remaja Awal: Temuan Baseline Dari Rencana Program Self-Instructional Training Kompetensi Diri," Jurnal Psikologi Insight 2, no. 1 (2018): 43-56. 
mewadahi kalangan anak-anak untuk belajar membaca Alquran serta membuka privat bagi orang dewasa. Pada tahun 2018, Pesantren DHI mulai membuka program menghafal Alquran khusus untuk santri putri. Hal ini dilatarbelakangi oleh jumlah pesantren tahfidz khusus putri di Indonesia yang masih sedikit. Sehingga untuk menyeimbangkan jumlah para hafidz dan hafidzah di Indonesia, didirikanlah Pesantren Tahfidz DHI khusus putri. Ratarata santri yang masuk ke DHI merupakan remaja yang baru lulus dari SMA dan sederajat. Hal tersebut bertujuan agar anak tersebut dapat memanfaatkan waktu satu tahunnya untuk menghafal Alquran sebagai bekal melanjutkan ke perguruan tinggi. Di samping itu, berdirinya Pesantren DHI dilatarbelakangi oleh permasalahan metode menghafal Alquran yang diterapkan di Indonesia sudah klasik dan kurang efektif. Sehingga didirikanlah Pesantren DHI wadah untuk mengembangkan metode menghafal Alquran dengan cepat, paham, dan mutqin.

Awalnya Pesantren Tahfidz DHI hanya menyediakan satu tempat berupa rumah biasa yang ditempati sekitar 20 orang santri. Tentunya hal tersebut bertujuan untuk menciptakan suasana belajar yang kondusif. Kemudian Pesantren Tahfidz DHI terus berkembang hingga memiliki 13 cabang di berbagai daerah di Indonesia, seperti Bogor, Jakarta, Bekasi, Banten, Jember, dan Bukittinggi. Baru pada Tahun 2019 Pesantren DHI membuka pondok tahfidz khusus untuk putra. Di tahun 2019, Pesantren DHI berhasil mewisuda 108 santri dan hingga saat ini telah mencapai 177 santri yang hafal Alquran khatam 30 juz. Sekarang Pesantren Tahfidz DHI sudah memiliki santri sekitar 200 orang santri dengan 30 lebih pengajar.

Visi Pesantren Tahfidz DHI adalah terbentuknya generasi Qur'ani yang berilmu dan beradab sebagai calon pemimpin bangsa. Dalam mencapai visi tersebut, Pesantren Tahfidz DHI berupaya menanamkan adab dan nilai-nilai Alquran dalam setiap aspek kehidupan; mencetak hafidz Alquran yang berpegang teguh kepada Alquran dan Sunnah; serta mewujudkan lembaga tahfidz yang mampu menjawab tantangan zaman. Dalam menjalankan misinya, saat ini Pesantren Tahfidz DHI memiliki beberapa program di antaranya: karantina satu tahun (Hafal, Paham, Mutqin), dauroh 40 hari menghafal 30 juz, Program Mutqin enam bulan, Program SMP dan SMA Tahfidz, Tahfidz Anak 4 SD (Program 3 Tahun), Program Tahfidz Difabel, Program Internasional Class, dan DHI Institute (S1) khusus Hafidz Quran.

Metode pembelajaran menghafal Alquran yang dipakai di Pesantren DHI ini disebut dengan Metode Tawazun. Metode Tawazun sendiri ditemukan dan dikembangkan oleh Ustadz Marzul Fuardi. Metode tersebut sudah diterapkan di 13 Cabang Pesantren Tahfidz DHI sejak tahun 2018. Beliau merupakan pendiri sekaligus pimpinan Pesantren DHI dan salah satu Dosen Studi Islam di Universitas Ibnu Khaldun Bogor (UIK Bogor). Melalui 
metode ini diharapkan mampu memudahkan dan menarik banyak orang khususnya remaja untuk belajar menghafal Alquran.

\section{Metode Tahfidz Tawazun}

\section{Konsep Metode Tawazun dalam Menghafal Alquran}

Istilah Tawazun memiliki makna keseimbangan antara otak kanan dan otak kiri. Sehingga Metode Tawazun merupakan cara menghafal Alquran yang mengoptimalkan fungsi otak kanan dan otak kiri secara seimbang. Metode ini dapat membantu meningkatkan fokus seseorang dalam menghafal dan memaksimalkan fungsi otak secara seimbang. Pemanfaatan kedua fungsi otak secara seimbang tersebut dapat menghasilkan kualitas hafalan yang baik. Selain itu, metode tersebut juga dapat membantu memudahkan dalam menghafal Alquran bagi mereka yang sulit menghafal. Hal tersebut berdasarkan pemaparan Ustadz Fuardi:

"Terus itu yah metode, metode yang klasik itu kita ubah menjadi metode yang baru untuk menyeimbangkan otak kanan namanya Tawazun artinya keseimbangan antara otak kanan dan otak kiri. Jadi orang-orang yang susah ngafal supaya dia itu ada bisa lebih meningkatkan fokusnya dan memaksimalkan fungsi otak, otak kiri dan otak kanannya."

Dalam Metode Tawazun, pemanfaatan otak kanan dilakukan dengan cara melatih otak untuk menghafal cepat dengan menetapkan target hafalan sebanyak 15 halaman perhari. Sedangkan pemanfaatan otak kiri dilakukan dengan cara melancarkan hafalan atau mutqin melalui muroja'ah. Pesantren DHI menetapkan target muroja'ah sebanyak dua juz dalam sepekan untuk program mutqin enam bulan. Sedangkan untuk program mutqin satu tahun, target muroja'ah dalam sepekan sebanyak satu juz.

Berdasarkan penjelasan Ustadz Fuardi, Metode Tawazun memiliki dua tahap yaitu ziyadah (menambah hafalan) hingga khatam 30 juz, setelah itu tahap muroja'ah (mengulang kembali hafalan). Ziyadah merupakan proses di mana seseorang menambah hafalan baru. Ketika tahap ziyadah, seseorang sedang menggunakan otak kanannya. Sehingga hafalan yang dihasilkannya merupakan memori jangka pendek. Artinya seseorang akan mudah lupa dengan hafalan yang telah diperolehnya. Kemudian tahap berikutnya adalah mengulangulang hafalan yang sudah disetorkan santri dari juz pertama hingga juz 30 (muroja'ah). Ketika seseorang melakukan muroja'ah berarti dia sedang menggunakan otak kirinya. Sehingga hafalan yang dihasilkannya merupakan memori jangka panjang. Dengan demikian, muroja'ah dapat membantu seseorang memperkuat hafalannya (mutqin). Ketika proses memutqinkan hafalan tersebut menunjukkan bahwa seseorang sedang memindahkan hafalan 
dari otak kanan ke otak kiri. Sehingga yang tadinya hafalan santri bersifat jangka pendek berubah menjadi memori jangka panjang.

Penggunaan Metode Tawazun dalam menghafal Alquran dapat membuat seseorang cepat dalam menghafal ayat. Selain itu, Metode Tawazun dapat meringankan seorang penghafal Alquran secara psikologis. Hal tersebut karena pembagian waktu ziyadah dan muroja'ah dapat meringankan beban kerja otak. Sehingga membuat santri tidak stres ketika menghafal Alquran. Selain itu, menghafal dengan Metode Tawazun dapat menciptakan rekor hafalan sebanyak 54 halaman dalam satu hari.

\section{Teknik-Teknik Menghafal Alquran dengan Metode Tawazun}

Ada beberapa teknik menghafal Alquran menggunakan Metode Tawazun yaitu membaca, memahami, membayangkan, menghafalkan, dan menyetorkan. Teknik pertama adalah seorang penghafal membaca ayat yang hendak dihafal dengan baik, tartil, dan tidak tergesa-gesa. Hal ini tentunya agar tidak terjadi kesalahan ketika membaca Alquran. Tidak perlu terlalu banyak membaca ayat yang hendak dihafal, cukup tiga atau lima kali saja. Metode Tawazun tidak menargetkan membaca ayat yang hendak dihafal dalam jumlah banyak. Hal ini karena Metode Tawazun tidak fokus pada banyaknya mengulang bacaan, tapi menghafal sampai seseorang tersebut hafal.

Teknik kedua yaitu memahami ayat demi ayat yang hendak dihafal. Dalam memahami ayat, santri diminta untuk mencari kosa kata baru, kemudian diberi tanda dan dihafalkan. Setelah itu, mencari clue (petunjuk) seperti 'ain, hizb atau ayat populer untuk membantu memudahkan dalam mengingat. Setelah menemukan petunjuknya, santri memahami per tema ayat (per 'ain) seperti mengahafalkan cerita. Sehingga dalam satu halaman santri hanya menghafal kosa kata baru dan menyusun kalimat yang sudah dihafal pada halaman sebelumnya. Oleh karena itu, mushaf yang dipakai untuk menghafal dengan metode ini menggunakan mushaf Alquran yang memiliki terjemah per katanya. Penggunaan Mushaf Alquran terjemah bertujuan agar santri dapat memahami maksud ayat yang dihafalkannya. Dalam memegang mushaf diusahakan harus sejajar dengan mata dan tidak menunduk. Tentunya hal tersebut untuk menjaga santri agar tetap fokus dengan ayat yang dihafalkannya. Selain itu, posisi mata tersebut dapat memudahkan seseorang dalam mengingat kembali setiap halaman yang sedang dihafalnya (Majdi Ubaid Al-Hafizh 2014).

Teknik ketiga yaitu membayangkan atau scan satu halaman Alquran yang hendak dihafalkan di otak sebaik mungkin. Bagian-bagian yang perlu dibayangkan oleh santri meliputi: jumlah halaman dalam Alquran yang terdapat 604 halaman; satu juz terdapat 20 halaman dan permulaan juz yang ada di sebelah kiri; kelipatan setengah juz per 10 halaman; 
kelipatan seperempat juz per 5 halaman; posisi halaman sebelah kiri dan kanan; menghitung jumlah ayat dalam satu halaman; dan mengingat letak atau posisi ayat yang sedang dihafal.

Teknik keempat yaitu menghafal ayat yang sedang dihafal dengan fokus dan menghadirkan pikiran (live the moment) selama 60 menit. Menghafal dilakukan dengan tidak melihat mushaf, sebab menghafal merupakan pekerjaan otak bukan pekerjaan lisan atau mata. Santri hanya boleh melihat mushaf ketika lupa saja dengan cara melihat mushaf di sebelah kanan atas. Dalam teknik ini, santri menghafalkan ayat sebanyak satu halaman mulai dari merangkai setiap kata dalam satu baris sampe ayat per ayat. Kemudian, menghafalkan setiap permulaan ayat yang sedang dihafal. Setelah itu, menggabungkan ayat per ayat yang telah dihafal menjadi satu halaman.

Teknik yang kelima adalah menyetorkan hafalan per halaman dengan tartil kepada guru. Selama santri menyetorkan hafalannya, guru menyimaknya dengan baik dan seksama dari awal hingga selesai. Ketika menyetorkan hafalan, hendaknya santri tidak melebihi tiga kali kesalahan. Jika melebihi tiga kali kesalahan atau santri lupa dengan ayat dalam satu baris, maka dinyatakan gagal. Tapi jika bagian ayat yang terlupanya tidak terlalu banyak, maka guru akan memberitahunya dengan memberikan makna katanya terlebih dahulu. Jika gagal, maka santri menghafal kembali di samping guru dengan menghadap tembok dan menyetorkan kembali setelah 10 menit kemudian.

Berdasarkan hasil wawancara dengan Ustadz Fuardi, dapat dijelaskan bahwa sebelum menghafal Alquran, ada beberapa hal yang harus diperhatikan. Pertama, seorang harus melakukan pendekatan dengan Alquran terlebih dahulu. Pendekatan dengan Alquran dapat dilakukan dengan cara membaguskan bacaan dan sesuai dengan tajwid; mengkhatamkan bacaan Alquran sesering mungkin; serta memahami Alquran dengan membaca terjemahannya.

Kedua, persiapan spiritual yang dapat dilakukan dengan cara berdoa kepada Allah SWT agar dijadikan sebagai ahlul Quran. Kemudian sesering mungkin bertaubat kepada Allah SWT dengan sholat dan memperbanyak dzikir. Karena banyaknya dosa dapat mengakibatkan seseorang susah dalam menghafal. Selain itu, membersihkan jiwa dengan cara menjaga niat yang ikhlas untuk menghafal Alquran. Kemudian menjaga amalan ibadah mahdhah (wajib) dan ghairu mahdhoh (sunnah).

Ketiga, persiapan mental. Seseorang yang ingin menghafal Alquran di DHI harus memiliki tekad yang kuat untuk menjadi seorang hafiz. Mengingat jadwal kegiatan menghafal Alquran di DHI sangat padat, dengan target hafalan yang cukup banyak. Selain itu, seseorang perlu merubah mindset jika menghafal itu mudah. Kemudian menghafal 
dengan penuh syukur dan bahagia. Persiapan mental ini sangat penting, sebab jika mental santri tidak siap, maka santri akan mudah putus asa.

Metode Tawazun yang diterapkan di Pesantren DHI telah melewati proses penelitian yang cukup panjang. Awalnya pembelajaran menghafal Alquran dengan Metode Tawazun dibagi menjadi dua tahapan. Tahap pertama, santri menambah hafalan (ziyadah) dan (muroja'ah) sampai mencapai 15-20 juz. Kemudian tahap berikutnya adalah dauroh, di mana santri menghafal ayat yang menjadi kekurangannya untuk khatam 30 juz tanpa muroja'ah. Namun, cara tersebut mengakibatkan waktu untuk muroja'ah sangat sedikit. Sehingga Ustadz Fuardi membuat perubahan yang cukup signifikan terhadap Metode Tawazun.

Dalam pelaksanaanya, Metode Tawazun yang dipakai saat ini terbagi menjadi lima level. Level satu, khusus untuk proses ziyadah dan selebihnya level untuk proses memutqinkan dengan cara mengulang kembali hafalan yang sudah dimilikinya (muroja'ah).

Pada level satu, santri yang baru masuk ke Pesantren DHI harus mengikuti dauroh selama 40-60 hari atau lebih. Lamanya waktu dauroh tergantung pada kemampuan anak dalam menghafal Alquran. Dalam kegiatan dauroh, santri hanya fokus untuk menambah hafalan (ziyadah) dan menyetorkannya per halaman kepada ustadzah hingga khatam 30 juz. Kegiatan dauroh ini bertujuan untuk memaksimalkan fungsi otak kanan secara optimal. Hafalan yang dihasilkan dalam level ini berupa ingatan jangka pendek (sort term memory) atau ingatan yang mudah lupa.

Jika santri telah menyelesaikan ziyadahnya pada level 1, maka santri boleh melanjutkan hafalannya ke level 2. Tahap ini merupakan level pertama untuk memutqinkan hafalan santri. Pada level 2, santri diminta untuk mengulang kembali hafalan ayat dari juz 1 sampai juz 30 (muroja'ah). Dalam sehari santri harus menyetorkan hafalan minimal sebanyak 5 halaman dalam satu hari. Jika santri telah menyetorkan hafalan sebanyak satu juz, maka harus mengikuti ujian dengan menyetorkan hafalan satu juz tersebut dalam sekali duduk. Seperti itu seterusnya sampai santri khatam 30 juz. Jadi, di level 2 santri akan melaksanakan ujian sebanyak 30 kali.

Jika santri lulus ujian di level 2, maka ia boleh lanjut ke level 3. Pada level 3, santri kembali mengulang hafalannya (muroja'ah) dari juz 1 sampai juz 30. Hafalan santri akan diuji, jika setoran hafalannya telah mencapai lima juz. Ujiannya yaitu santri diminta untuk mengulangi kembali (muroja'ah) lima juz tersebut dalam sehari (boleh tidak sekali duduk). Proses tersebut terus berlangsung hingga santri khatam 30 juz. Dengan demikian, pada level ini santri akan melaksanakan ujian sebanyak enam kali. 
Setelah mengikuti enam kali ujian di level 3, santri boleh melanjutkan ke level 4. Di level 4, santri kembali mengulang hafalannya (muroja'ah) dari juz 1 sampai juz 30 dan melaksanakan ujian per 10 juz. Artinya setelah santri menyetorkan hafalannya sebanyak 10 juz, maka hafalan tersebut akan diuji. Ujian tersebut dilakukan dalam sehari dengan penilaian tertulis (boleh tidak sekali duduk). Dengan demikian, pada level 4, santri akan melaksanakan tiga kali ujian.

Jika santri sudah berhasil menyelesaikan tiga kali ujian pada level 4, maka boleh melanjutkan ke level 5. Pada level 5 ini, santri mengulang kembali hafalannya (muroja'ah) dari juz 1 sampai juz 30. Pada level ini dilaksanakan munaqasyah kubro yaitu ujian dengan menyetorkan hafalan 30 juz dalam sekali duduk di hadapan dua guru dengan penilaian tertulis. Munaqasyah merupakan puncaknya menghafal Alquran dengan Metode Tawazun.

Konsep Metode Tawazun juga dapat terlihat dalam jadwal keseharian santri di Pesantren DHI. Di mana, tiga sesi pertama dialokasikan untuk menambah hafalan (ziyadah) dan meyetorkannya kepada guru. ini menunjukkan bahwa pada tiga sesi pertama santri difokuskan untuk menggunakan otak kanannya secara optimal. Sedangkan tiga sesi berikutnya digunakan untuk mengulang kembali hafalan santri (muroja'ah). Hal tersebut menunjukkan bahwa tiga sesi terakhir santri difokuskan untuk menggunakan otak kirinya secara optimal. Sehingga kegiatan menghafal Alquran dalam sehari, santri memanfaatkan kedua otaknya secara seimbang.

Kegiatan muraja'ah di Pesantren DHI dibagi menjadi tiga metode yaitu sabki, rabt, dan manzili. Sabki merupakan mengulang kembali hafalan (muraja'ah) per lima halaman dan disetorkan sekali duduk kepada guru. Rabt yaitu muroja'ah sebanyak satu juz pada juz yang sedang dimutqinkan. Manzili merupakan muraja'ah pribadi sebanyak tiga juz (10\% dari jumlah hafalan) setiap hari. Kegiatan muraja'ah harus dilakukan bersama partner. Muraja'ah dilakukan bertujuan untuk menguatkan hafalan santri dan agar tidak lupa dengan hafalan yang sudah dimiliki.

Ada beberapa hal yang dapat menunjang keberhasilan penerapan Metode Tawazun dalam pembelajaran menghafal Alquran. Penunjang tersebut terbagi menjadi dua macam yaitu penunjang yang bersifat dzahir (terlihat jelas) dan bathin (tidak kelihatan). Penunjang yang bersifat dhazir meliputi Mushaf Alquran Terjemah, papan untuk meletakkan Alquran, guru, tempat yang nyaman dan kondusif, dan makanan yang sehat.

Adapun faktor penunjang yang berifat bathin meliputi kemampuan membaca Alquran dengan baik; keinginan yang kuat untuk menghafal Alquran; kesungguhan ketika 
menghafal; kemampuan; kesabaran dalam menghafal; niat yang lurus; kesehatan jasmani, dan kegiatan yang dapat membantu memudahkan menghafal Alquran.

Kegiatan tersebut salah satunya adalah mentadabburi Alquran melalui pembelajaran tafsir ayat yang diberikan oleh ustadzah. Kegiatan Tadabbur Alquran bertujuan agar ayat itu benar-benar sampai ke dalam hati kemudian teraplikasi dalam keseharian. Selain itu ada Sholat Tahajjud berjama'ah yang diimami oleh santri setiap malam. Biasanya dalam Tahajjud tersebut santri membaca ayat sebanyak setengah juz. Tentu kegiatan ini dapat memperkuat hafalan santri. Kemudian ada kegiatan muhadatsah yaitu belajar kosa kata Bahasa Arab yang dilaksanakan dua kali dalam sepekan. Kegiatan ini sangat bermanfaat untuk menambah mufrodat santri, sehingga dapat memudahkannya ketika menghafal Alquran. Selain itu Pesantren DHI juga mengadakan kegiatan ujian sambung ayat khusus untuk anak-anak yang sedang menjalankan program mutqin.

Dalam Penerapan Metode Tawazun dalam pembelajaran menghafal Alquran di Pesantren DHI Cabang Sentul, santri dibagi menjadi dua halaqah. Halaqah pertama yaitu halaqah dauroh dan halaqah mutqin. Halaqah daurah merupakan halaqah atau kelompok untuk santri yang masih dalam proses menyelesaikan tahap daurah. Sedangkan halaqah mutqin adalah kelompok untuk santri yang sedang menjalankan program mutqin.

\section{Metode Tawazun dan General Self-esteem}

Kontribusi yang diberikan Metode Tawazun dalam konteks penelitian ini yaitu manfaat yang diperoleh santri baik berupa pengetahuan maupun pengalaman ketika menghafal Alquran dengan Metode Tawazun. Manfaat tersebut kemudian memberikan pengaruh terhadap peningkatan general self-esteem. General self-esteem merupakan harga diri yang diperoleh seseorang dari dirinya secara keseluruhan. Menurut Battle, general selfesteem dapat mempengaruhi tujuan, aktivitas yang sedang dijalani, serta penentuan sikap dan perilaku seseorang.

Dalam menjelaskan peningkatan general self-esteem, penulis memaparkannya per indikator sebagai berikut:

Tabel 1. Perasaan Berharga (memiliki sikap dan perilaku yang positif)

\begin{tabular}{|c|c|l|}
\hline No & Responden & Perasaan Berharga (memiliki sikap dan perilaku yang positif) \\
\hline 1 & A & $\begin{array}{l}\text { Hafalan Alquran yang dimilikinya membuatnya menjadi lebih } \\
\text { sabar, bersyukur, menjaga perkataannya, tidak mudah marah, } \\
\text { beriman kepada Allah SWT dan menjalankan perintah-Nya, lebih } \\
\text { husnudzan kepada Allah SWT }\end{array}$ \\
\hline
\end{tabular}




\begin{tabular}{|c|c|l|}
\hline 2 & B & $\begin{array}{l}\text { Hafalan Alquran yang diperolehnya melalui Metode Tawazun, } \\
\text { membuatnya lebih mampu menahan emosi }\end{array}$ \\
\hline 3 & C & $\begin{array}{l}\text { Hafalan Alquran yang diperolehnya melalui Metode Tawazun, } \\
\text { membuatnya lebih lembut dalam bertutur kata, lebih rajin } \\
\text { menjalankan perintah Allah SWT }\end{array}$ \\
\hline 4 & D & $\begin{array}{l}\text { Menjadi lebih sabar, mampu menahan emosi, lebih serius dalam } \\
\text { menghafal Alquran dan berusaha menerapkannya dalam } \\
\text { keseharian, mau membantu orang tua, memanfaatkan waktu } \\
\text { sebaik mungkin, lebih khusyuk dalam sholat, lebih menjaga } \\
\text { adabnya terhadap Alquran }\end{array}$ \\
\hline
\end{tabular}

Sumber: Hasil Wawancara Responden

Berdasarkan hasil wawancara di atas, menunjukkan bahwa $100 \%$ responden dalam penelitian ini memiliki sikap dan perilaku positif setelah menghafal Alquran dengan Metode Tawazun. Responden A merasa bahwa hafalan yang diperolehnya melalui Metode Tawazun telah membawa perubahan yang lebih baik pada sikap dan perilakunya. Sebelumnya, Responden menilai dirinya sebagai seorang yang nakal, jauh dari syariat Allah; tidak menerima takdir Allah, selalu mengeluh dengan takdir Allah SWT; menghabiskan waktu dengan sia-sia seperti nongkrong, pacaran, bermain HP; tidak mampu menahan emosi (mudah marah), menyakiti diri sendiri; dan sering beradu fisik dengan saudaranya.

Sikap dan perilaku negatif tersebut menunjukkan bahwa General Self-esteem Responden A sangat rendah. Berdasarkan teori Battle self-esteem merupakan variabel indenpenden yang menjadi sebab seseorang berperilaku. Sikap negatif yang ditunjukkan Responden A sebelum menghafal Alquran menunjukkan bahwa Responden A belum bisa menganggap bahwa dirinya berharga.

Berbeda keadaannya setelah menghafal Alquran, penilaian Responden A terhadap sikap dan perilaku dirinya semakin baik. Responden merasa bahwa hafalan Alquran yang dimilikinya telah mengubahnya menjadi orang yang lebih sabar, bersyukur, menjaga perkataannya, tidak mudah marah, lebih beriman kepada Allah SWT, menjalankan perintahNya, lebih husnudzan kepada Allah SWT.

Perubahan sikap dan perilaku tersebut sebagai kontribusi dari penggunaan Metode Tawaun dalam menghafal Alquran. Di mana pada prosesnya santri tidak hanya dituntut untuk menghafal ayatnya saja, melainkan juga harus memahami arti dan menghayatinya. Sehingga nilai-nilai positif dalam Alquran dapat teriternalisasi dalam sikap dan perilakunya sehari-hari.

Cukup jauh berbeda dengan Responden B yang sebelumnya pernah menghafal Alquran. Penulis melihat peningkatan sikap dan perilaku positif responden tidak terlalu signifikan. Perubahan tersebut dapat terlihat dari cara Responden mengendalikan emosinya. 
Sebelum menghafal Alquran dengan Metode Tawazun santri merasa kurang mampu dalam mengendalikan emosinya secara positif. Namun setelah menghafal Alquran dengan Metode Tawazun, dirinya dapat menunjukkan sikap positif ketika ada masalah dengan orang lain dan emosinya menjadi lebih stabil ketika dihadapkan pada suatu masalah.

Berdasarkan hasil wawancara dengan Responden C, dirinya merasa ada perubahan dari sikap dan perilakunya antara sebelum dan sesudah menghafal Alquran dengan Metode Tawazun. Sebelumnya responden pernah menghafal Alquran sebanyak tiga juz, namun hafalannya tersebut tidak dapat mencegahnya dari perbuatan maksiat dan hawa nafsunya. Responden $\mathrm{C}$ mengakui bahwa saat itu sikapnya dalam bertutur kata masih terlalu kasar. Berdasarkan teori Battle, terkait hal tersebut menunjukkan bahwa Responden memiliki general self-esteem yang rendah. Namun, setelah menghafal Alquran dengan Metode Tawazun, responden merasa lebih lembut dalam bertutur kata, dan lebih rajin menjalankan perintah Allah SWT.

Penulis berasumsi bahwa sikap positif tersebut merupakan dampak positif dari menghafal Alquran dengan Metode Tawazun. Di mana menghafal melalui metode ini, santri bukan sekadar menghafal melainkan juga memahami makna ayat yang dihafalnya. Sehingga hafalan tersebut lebih membekas dalam hati dan pikirannya serta dapat terimplementasi dalam sikap dan perilakunya.

Tidak jauh berbeda dengan Responden C, Responden D yang sebelumnya pernah menghafal Alquran juga merasakan adanya perubahan dari sikap dan perilakunya setelah menghafal Alquran dengan Metode Tawazun. Sebelumnya responden menilai dirinya kurang dapat mengendalikan emosi negatif (mudah marah), menghabiskan waktunya dengan hal yang tidak bermanfaat, malas, dan tergesa-gesa ketika sholat. Sikap dan perilaku tersebut menunjukkan bahwa responden tidak dapat menghargai dirinya secara positif, meskipun saat itu posisinya sudah menghafal Alquran. Namun, sikap dan perilakunya tidak mencerminkan seorang penghafal Alquran sejati. Responden mengakui bahwa hafalan yang diperolehnya pada saat itu tidak terlalu memberikan pengaruh pada sikap dan perilakunya.

Berbeda keadaannya setelah menghafal Alquran dengan Metode Tawazun, Responden D merasa dirinya lebih sabar; mampu menahan emosi; lebih serius dalam menghafal Alquran dan berusaha menerapkannya dalam keseharian; ada keinginan membantu orang tua; memanfaatkan waktu sebaik mungkin; lebih khusyuk dalam sholat; serta lebih menjaga adabnya terhadap Alquran (Ismi Fitriani, (wawancara pribadi), 29 Mei 2020). Perubahan sikap dan perilaku tersebut menunjukkan adanya peningkatan general selfesteem. Peningkatan tersebut merupakan kontribusi dari penggunaan Metode Tawazun 
dalam menghafal Alquran. Di mana adanya teknik memahami ayat, santri dapat lebih memahami makna ayat yang dihafalnya dan merasa bertanggung jawab untuk menjaga hafalan tersebut. Sehingga responden berupaya menerapkan nilai-nilai Alquran yang telah dihafalnya dalam kehidupan sehari-hari.

Dari pemaparan di atas, dapat disimpulkan bahwa Metode Tawazun telah memberikan kontribusi positif secara tidak langsung terhadap peningkatan general selfesteem pada indikator sikap dan perilaku. Peningkatan tersebut terlihat dari perubahan yang semakin baik dari sikap dan perilaku para responden setelah menghafal Alquran dengan Metode Tawazun.

\section{Tabel 2. Tujuan Hidup Yang Tinggi}

\begin{tabular}{|c|c|l|}
\hline No & Responden & \multicolumn{1}{c|}{ Tujuan hidup yang tinggi } \\
\hline 1 & A & $\begin{array}{l}\text { Hafalan Alquran yang dimilikinya membuatnya bercita-cita untuk } \\
\text { terus belajar dan mengamalkan Alquran kepada diri sendiri dan } \\
\text { orang disekitarnya }\end{array}$ \\
\hline 2 & B & $\begin{array}{l}\text { Bukan hanya sekadar mutqin namun dapat masuk ke dalam hati } \\
\text { dan mengaplikasikan nilai-nilai Alquran dalam kehidupan sehari- } \\
\text { hari }\end{array}$ \\
\hline 3 & C & $\begin{array}{l}\text { Hafalan Alquran yang diperolehnya membuatnya ingin selalu } \\
\text { menjaga hafalan tersebut bagaimanapun keadaannya }\end{array}$ \\
\hline 4 & D & $\begin{array}{l}\text { Hafalan yang diperolehnya membuatnya ingin menjaga hafalan } \\
\text { tersebut untuk mendekatkan diri kepada Allah dan sebagai } \\
\text { baktinya kepada orang tua }\end{array}$ \\
\hline
\end{tabular}

Sumber: Hasil Wawancara Responden

Dalam indikator tersebut, $100 \%$ responden dalam penelitian ini memiliki tujuan hidup yang tinggi setelah menghafal Alquran dengan Metode Tawazun. Sebelum Responden A menghafal Alquran, dirinya tidak memiliki tujuan hidup yang jelas. Hal tersebut terlihat dari sikap responden yang tidak bisa memaknai dirinya dan hidupnya secara positif. Selalu mengeluh dan ingin bunuh diri ketika menghadapi masalah. Bahkan ketika itu dirinya mengatakan sendiri bahwa dirinya tidak mengetahui tujuan hidupnya dan tujuan Allah menciptakan dirinya. Namun, setelah menghafal Alquran dengan Metode Tawazun dirinya mengetahui tujuan hidupnya saat ini yaitu menjadi sebaik-baiknya manusia dengan belajar dan mengamalkan Alquran (Saila, (wawancara pribadi), 28 Mei 2020)

Peningkatan tujuan hidup juga terlihat pada Responden B, C, dan D yang sebelumnya pernah menghafal Alquran. Sebelum masuk DHI, Responden B bercita-cita ingin mengkhatamkan Alquran. Namun setelah khatam Alquran dengan Metode Tawazun, ia ingin terus menjaga hafalan dan dapat terinternalisasi dalam hati dan perilaku sehari-harinya. Hal tersebut menunjukkan adanya peningkatan tujuan hidup pada Responden B. Adanya 
peningkatan tujuan hidup tersebut, karena hikmah yang telah diperolehnya melalui teknik memahami ayat yang dihafalnya.

Begitupun dengan Responden C, sebelum masuk DHI ia memiliki cita-cita untuk melanjutkan studinya di perguruan tinggi negeri. Namun gagal karena ada suatu halangan, akhirnya dia memilih untuk menghafal Alquran. Responden mengakui bahwa awalnya pilihannya untuk menghafal Alquran hanya sebagai pelampiasan. Kemudian, setelah responden mengkhatamkan hafalan Alquran dengan Metode Tawazun, responden ingin terus menjaga hafalan Alqurannya bagaimanapun keadaannya. Bahkan jika dirinya ingin bekerja, dirinya berharap mendapat pekerjaan yang tidak menganggu waktu muroja'ahnya.

Di samping itu, setelah menghafal Alquran dengan Metode Tawazun, Responden D berharap dirinya dapat terus menjaga hafalan Alquran untuk mendekatkan diri kepada Allah dan sebagai baktinya kepada orang tua. Harapannya tersebut menunjukkan adanya tujuan hidup yang tinggi. Alasannya untuk terus muroja'ah hafalan Alquran karena sekarang merasa bahwa menghafal Alquran merupakan pekerjaan seumur hidup. Namun keinginan tersebut tidak terbesit dalam hatinya ketika menghafal Alquran dengan metodenya sendiri. Hal ini menunjukkan bahwa menghafal dengan Metode Tawazun dapat membuat santri lebih menghayati Alquran dan lebih menikmatinya.

Dari pemaparan di atas menunjukkan bahwa responden menganggap hafalan yang diperolehnya melalui Metode Tawazun sebagai hal yang berharga. Sehingga mereka melakukan berbagai cara agar hafalan Alquran tersebut tidak hilang dalam dirinya. Dengan demikian, dapat disimpulkan bahwa penggunaan Metode Tawazun dalam menghafal Alquran memberikan kontribusi positif secara tidak langsung terhadap general self-esteem santri pada indikator tujuan hidup.

\section{Kontribusi Metode Tawazun terhadap Peningkatan Social Self-esteem}

Kontribusi Metode Tawazun dalam konteks penelitian ini adalah manfaat yang dirasakan santri dari menghafal Alquran dengan metode tersebut. Dari manfaat tersebut memberikan kontribusi yang positif terhadap peningkatan social self-esteem santri. Battle mengemukakan bahwa social self-esteem merupakan harga diri yang diperoleh dari persepsi individu terhadap hubungannya dengan teman sebaya. Social self-esteem berkaitan dengan kemampuan seseorang dalam berinteraksi dengan orang lain.

Deskripsi harga diri setiap santri di Pesantren DHI Cabang Sentul dalam aspek social self-esteem dapat digambarkan per indikator, sebagai berikut:

Tabel 3. Perasaan Diterima Oleh Lingkungan

\begin{tabular}{|c|c|c|}
\hline No & Responden & Tujuan hidup yang tinggi \\
\hline
\end{tabular}




\begin{tabular}{|c|c|c|}
\hline 1 & $\mathrm{~A}$ & $\begin{array}{l}\text { Hafalan Alquranyang dimilikinya membuatnya merasa bahwa } \\
\text { keluarganya bangga terhadapnya dan merasa bahwa dirinya dapat } \\
\text { memberikan pengaruh positif terhadap keluarganya }\end{array}$ \\
\hline 2 & $\mathrm{~B}$ & \multirow{3}{*}{$\begin{array}{l}\text { Merasa bahwa keluarganya lebih bangga terhadapnya setelah hafal } \\
\text { Alquran } 30 \text { juz }\end{array}$} \\
\hline 3 & $\mathrm{C}$ & \\
\hline 4 & $\mathrm{D}$ & \\
\hline
\end{tabular}

Sumber: Hasil Wawancara Responden

Terkait indikator di atas, Responden A merasakan ada perbedaan dari sikap orangorang sekitanya ketika sebelum dan setelah menghafal Alquran. Sebelum menghafal Alquran, tepatnya ketika dia ingin melanjutkan studi ke jenjang sekolah menengah atas, dirinya merasa bahwa orang-orang di sekitarnya tidak menghargai dirinya. Hal ini karena Responden A memutuskan untuk tidak melanjutkan studinya ke SMA Negeri seperti yang diharapkan keluarga, guru dan teman-temannya. Responden A memilih untuk melanjutkan studinya ke pesantren. Menurutnya saat itu, orang-orang di sekitarnya menganggap bahwa keputusannya tersebut sebagai cita-cita yang rendah yang tidak dapat menghasilkan apa-apa (finansial dan status sosial). Melihat tanggapan mereka terhadap keputusannya membuat Responden A sedih dan menangis. Penulis berasumsi bahwa perasaan sedih tersebut menunjukkan adamya kekhawatiran pada Responden A terhadap tanggapan orang lain. Kondisi tersebut mengindikasikan bahwa responden A memiliki social self-esteem yang rendah berdasarkan Teori Branden.

Bukan hanya dalam hal itu, Responden memang mudah depresi ketika ada masalah dengan orang lain hingga sering memutuskan untuk bunuh diri. Keadaan tersebut menunjukkan bahwa responden selalu merasa terancam dengan penilaian orang lain tentang dirinya. Responden merasa seolah-lah dirinya tidak diterima oleh lingkungannya.

Namun keadaan tersebut berbeda setelah Responden A menghafal Alquran yang telah memberikan banyak perubahan pada sikap dan perilakunya. Responden A merasa bahwa orang-orang di sekitarnya lebih bangga dan mendukung apa yang menjadi pilihannya yaitu menghafal Alquran. Dengan wajah berseri namun menunjukkan rasa tidak percaya, Responden menceritakan bahwa perubahan yang ada pada dirinya dapat memberikan motivasi positif pada keluarganya. Di mana karena dirinya, mereka ingin memutuskan untuk berhijab. Namun, penilaian orang lain terhadap dirinya saat ini tidak membuatnya superior melainkan tetap rendah hati. Meskipun memang penilaian tersebut membuatnya menjadi lebih semangat untuk terus menghafal Alquran. Sikap rendah hati yang ditunjukkan responden mengindikasikan bahwa Reponden A memiliki self-esteem yang tinggi. Asumsi tersebut berdasarkan Teori Rosenberg dan Owens bahwa orang dengan self-esteem tinggi mampu menerima pujian secara positif. 
Berdasarkan pemaparan di atas menunjukkan bahwa hafalan Alquran yang diperolehnya melalui Metode Tawazun telah meningkatkan perasaan diterima oleh lingkungan pada diri Responden. Dengan demikian, secara tidak langsung Metode Tawazun telah memberikan kontribusi positif terhadap peningkatan Social Self-esteem santri.

Perasaan semakin diterima juga dirasakan oleh Responden B, C, dan D setelah mengkhatamkan hafalan Alquran dengan Metode Tawazun. Perasaan tersebut berasal dari persepsinya tentang pandangan keluarganya terhadap dirinya. Di mana mereka melihat bahwa keluarganya, terlebih orang tuanya menjadi lebih bangga dengan prestasi hafalan Alquran yang dimilikinya saat ini. Keadaan tersebut mengindikasikan bahwa perasaan diterima pada diri responden meningkat. Sehingga dapat dikatakan bahwa secara tidak langsung Metode Tawazun telah meningkatkan social self-esteem santri di Pesantren DHI Cabang Sentul.

Tabel 4. Kemampuan Melibatkan Diri Dalam Interaksi Interpersonal Dalam Kehidupan Sosial

\begin{tabular}{|c|c|l|}
\hline No & Responden & $\begin{array}{l}\text { Kemampuan melibatkan diri dalam interaksi interpersonal } \\
\text { dalam kehidupan sosial }\end{array}$ \\
\hline 1 & A & $\begin{array}{l}\text { Hafalan yang dimilikinya membuat hubungannya dengan keluarga } \\
\text { semakin baik dan erat; tetap rendah hati ketika mendapat pujian }\end{array}$ \\
\hline 2 & B & $\begin{array}{l}\text { Hafalan yang dimilikinya membuatnya tetap rendah hati etika } \\
\text { mendapat pujian dari keluarganya }\end{array}$ \\
\hline 3 & C & $\begin{array}{l}\text { Rendah hati ketika mendapat pujian dari keluarganya; lebih baik } \\
\text { dalam bertutur kata }\end{array}$ \\
\hline 4 & D & $\begin{array}{l}\text { Hafalan yang dimilikinya mampu menciptakan hubungan yang } \\
\text { baik antara responden dengan keluarganya }\end{array}$ \\
\hline
\end{tabular}

Sumber: Hasil Wawancara Responden

Berdasarkan hasil wawancara, peneliti melihat ada peningkatan pada diri santri terkait indikator di atas setelah menghafal Alquran dengan Metode Tawazun. Peningkatan tersebut dapat terlihat dari penuturan Responden A. Di mana sebelum memiliki hafalan Alquran, responden merasa tidak terlalu dekat dengan keluarganya. Hanya untuk menegur sapa atau menanyakan kabar saja, dirinya masih merasa gengsi. Bahkan responden sering sekali bertengkar hingga adu fisik dengan saudaranya hanya karena masalah sepele. Hal tersebut karena pada saat itu responden merasa kesulitan dalam menahan emosinya.

Merujuk pada teori Rosenberg dan Owens, kondisi tersebut mengindikasikan bahwa Responden A memiliki social self-esteem yang rendah. Hal ini karena responden sulit berinteraksi dengan orang lain; merasa terancam dengan tanggapan orang lain, mudah marah, dan kurang dapat menunjukkan sikap positif terhadap orang lain. 
Berbeda kondisinya setelah menghafal Alquran, dirinya merasa lebih mampu menahan emosinya; merasa hubungannya dengan keluarganya semakin dekat dan baik. Selain itu, meskipun dirinya sudah mengkhatamkan hafalan Alquran, responden tetap merasa rendah hati terlebih ketika mendapat pujian dari keluarga dan teman sebayanya.Terciptanya hubungan baik antara Responden dengan keluarganya; serta sikap rendah hati menunjukkan bahwa santri memiliki kemampuan dalam berinteraksi dengan orang lain. Berdasarkan Teori Branden, keadaan tersebut menunjukkan bahwa responden memiliki social self-esteem yang tinggi.

Adapun pada Responden B dan C, tidak terlihat peningkatan social self-esteem terkait kemampuan melibatkan diri dalam interaksi interpersonal. Sedangkan pada Responden D dapat terlihat peningkatannya. Responden D mengakui sendiri bahwa sebelum menghafal Alquran dengan Metode Tawazun dirinya kurang mampu menahan emosinya sehingga mudah marah. Meskipun pada saat itu dirinya telah memiliki hafalan Alquran. Namun setelah menghafal dengan Metode Tawazun dirinya dapat lebih sabar dan mampu menahan emosi. Di mana ia selalu teringat dengan ayat Alquran yang menjelaskan bahwa Allah mencintai orang-orang yang sabar. Keadaan tersebut menunjukkan bahwa hafalan yang diperolehnya melalui Metode Tawazun lebih membekas dalam hatinya dibandingkan hafalanya yang dimiliki responden sebelumnya.

Manfaat yang dirasakannya tersebut mengakibatkan hubungan antara responden D dengan orang tuanya semakin baik. Di mana sebelumnya, responden kurang dapat menunjukkan sikap peduli pada orang tuanya. Misalnya saja ketika orang tuanya meminta tolong untuk membelikan sesuatu, Responden D tidak menghiraukannya. Berdasarkan Teori Coopersmith, sikap egois tersebut menunjukkan bahwa kemampuan melibatkan diri Responden dalam interaksi interpersonalnya masih kurang. Sehingga dapat dikatakan bahwa responden memiliki social self-esteem yang rendah.

Namun setelah Responden D menghafal Alquran dengan Metode Tawazun, dirinya merasa lebih dapat menahan egonya. Responden merasa bahwa saat ini dirinya lebih ingin membantu ibunya di rumah. Bahkan perjuangannya menghafal Alquran, ia persembahkan sebagai baktinya untuk orang tuanya. Hal tersebut menunjukkan bahwa dalam hubungan sosialnya antara Responden dan orang tuanya menjadi lebih baik. Sehingga dapat dikatakan bahwa setelah menghafal Alquran dengan Metode Tawazun, social self-esteem Responden D meningkat.

Perubahan tersebut tidak lepas dari manfaat yang diberikan Metode Tawazun dalam menghafal Alquran. Di mana responden tidak hanya menghafal melainkan juga dituntut 
untuk memahami, dan menghayati makna ayatnya. Sehingga sedikit banyak santri mengethaui kandungan dalam Alquran. Selain itu, hafalan yang telah diperolehnya melalui Metode Tawazun mendorong responden untuk menerapkan perintah Alquran dalam kehidupannya. Dengan demikian dapat disimpulkan bahwa secara tidak langsung Metode Tawazun memberikan kontribusi positif terhadap peningkatan social self-esteem.

\section{Penutup}

Sebagai penutup penulis telah menjelaskan Metode Tawazun yang terdiri atas proses membaca, memahami, membayangkan, menghafalkan dan menyetorkan. Aktivitas tersebut melatih kecerdasan otak kanan dan otak kiri secara seimbang dan optimal. Metode ini diterapkan di Pondok Tentang Pesantren Tahfidz D.aarul Huffadz Indonesia.

Metode ini terbukti bermanfaat dalam memudahkan santri dalam menghafal Alquran; memperoleh pemahaman tentang Alquran; menguatkan dan menjaga hafalan; menumbuhkan motivasi untuk menghafal serta menciptakan hubungan yang intensif antara santri dengan Alquran.

Implementasi metode tahfidz ini juga memberikan kontribusi positif terhadap peningkatan personal self-esteem yang ditandai dengan peningkatan perasaan bahagia, kemampuan dalam menghadapi tantangan, mengatasi masalah, dan memotivasi dirinya; serta penerimaan diri yang baik oleh lingkungannya dan hubungan yang baik dengan individu atau kelompok lain.

\section{E. Daftar Pustaka}

Balighoh, Nuzulul Hikmah. 2018. "Hubungan Antara Religiusitas Dan Kebermaknaan Hidup Dengan Kebahagiaan Penghafal Al-Qur'an Dewasa Awal.”

Bungin, Burhan. 2013. Metode Penelitian Sosial \& Ekonomi: Format-Format Kuantitatif Dan Kualitatif Untuk Studi Sosiologi, Kebijakan, Publik, Komunikasi, Manajemen, Dan Pemasaran Edisi Pertama. Jakarta: Kencana Prenada Media Group.

Fauziyyah, Muthi’, and Usmi Karyani. 2017. “Kesejahteraan Siswa: Studi Komparatif Siswa Berdasar Keikutsertaan Kegiatan Tahfidz." Indigenous: Jurnal Ilmiah Psikologi 2(2):193-200.

Febrina, Dilla Tria, Puji Lestari Suharso, and Airin Yustikarini Saleh. 2018. "Self-Esteem Remaja Awal: Temuan Baseline Dari Rencana Program Self-Instructional Training Kompetensi Diri.” Jurnal Psikologi Insight 2(1):43-56. 
Fitriani, Annisa. 2016. "Peran Religiusitas Dalam Meningkatkan Psychological Well Being.” xi(1).

Majdi Ubaid Al-Hafizh. 2014. 9 Langkah Mudah Menghafal Alquran. Solo: Aqwam Media Profetika.

Pangesti, Gita Windi. 2019. "Efektivitas Tadabbur Surah Al-Insyirah Terhadap Kebermaknaan Hidup Narapidana Muslim Di Lembaga Pemasyarakatan Perempuan (LPP) Klas II B Wirogunan Yogyakarta.” Universitas Islam Negeri Sunan Kalijaga.

Santrock, John W. 2007. Perkembangan Anak. 11th ed. Jakarta: PT Erlangga.

Wahid, Wiwi Alawiyah. 2014. Cara Cepat Bisa Menghafal Al-Qur'an. Yogyakarta: DIVA Press. 